\title{
The formation of a sustainable development strategy of the region
}

\author{
Vasyl Kozyk \\ Department of Economics of Enterprise \\ and Investment \\ Lviv Polytechnic National University \\ Lviv, Ukraine \\ Vasyl.V.Kozyk@lpnu.ua
}

\author{
Khrystyna Zalutska* \\ Department of Economics of Enterprise \\ and Investment \\ Lviv Polytechnic National University \\ Lviv, Ukraine \\ khrystyna.y.solovii@lpnu.ua
}

\author{
Oleg Tovkan \\ Department of Economics of Enterprise \\ and Investment \\ Lviv Polytechnic National University \\ Lviv, Ukraine \\ dmxrystja1@ rambler.ru
}

\begin{abstract}
The principles of forming a development strategy of the region based on the results of a comprehensive and detailed evaluation of the direct and indirect impact of economic entities on its structure have been highlighted. The matrix has been proposed and the peculiarities of the choice of the development strategy of the region depending on the determined level of influence of its business entities on the strategic capabilities of the region in specific directions have been described. The real and potential possible impact of the IT sphere on the structure of Lviv region has been shown, the options for directions of strategic development of the region have been determined. The possibilities of strategic directions of development of other economic structures of Lviv region, which are set by the implementation of strategic measures of regional development of its IT cluster, have been outlined. The formation of the options of the development strategy of the region through mutual impact of all its economic entities has been proven; it contributes to the formation of an effective regional structure that ensures successful long-term competitive development of the region both in the domestic and foreign markets by taking into account the available and possible strategic advantages and production capabilities of all, without the exception, its economic structures.
\end{abstract}

Keywords - strategy, development, region, IT companies, direct impact, indirect impact, matrix

\section{INTRODUCTION}

The condition for stable development and growth of the national economy is a stable and efficient functioning of the economy of its regions through the rational use of resources on the basis of a certain regional development strategy in the current realities. It is a long-term plan of the executive authorities, political, public organizations and associations of territorial communities, aimed at ensuring the effective development of the region, taking into account its own internal capacities and certain limits of the external environment. In addition, to develop an effective development strategy for the region, it is necessary to take into account not only the potential opportunities of its economic structures, but also their impact on the choice of the further strategic direction of movement of other economic entities of the region, which will ensure the effectiveness of this development by balancing the activities of the existing regional economic structures with the formation of appropriate long-term development scenarios.

\section{ANALYSIS OF RESEARCH AND PUBLICATIONS}

The research papers of the following scientists are devoted to the study of problems of strategic development of the regional economy: S. Bohuslavska [1], P. Vorona [2], S. Herasymchuk [3], R. Jovovic, M. Draskovic, M. Delibasic, and M. Jovovic [4], O. Kachnyi [5], O. Karyi [6], L. Katan [7], T. Kravchenko [8], O. Novikova, O. Amosha [9], M. Zveriakov [10], O. Prokopenko [11] and others.

Despite the considerable amount of studies that takes into account the competitive advantages and potentials of successful, potentially successful or promising business entities in the region when formulating regional strategies, the potential for long-term effective influence of regionally unattractive business entities on strategic directions in the long-term its development due to the increase owing to this efficiency of other perspective or potentially perspective regional economic entities. Therefore, there is a need to improve the existing conceptual approaches to the formation of a strategy for effective economic development of the region, taking into account, in addition to the external (state development priorities and desirable positions of the country in the international market), the internal environment of the region by determining the results of its business structures and their possible areas of strategic impact on the functioning of other regional economic entities.

\section{THE PURPOSE OF THE ARTICLE}

The purpose of the article is to develop theoretical, methodological and practical recommendations for the formation of a strategy for the development of a region by considering the level and direction of impact of its economic entities on the sectoral structure of the region.

\section{INFLUENCE OF IT CLUSTER ON DEVELOPMENT AND STRUCTURE OF ECONOMY OF LVIV REGION}

In order to achieve the set goal, the formation of the development strategy of Lviv region can be considered in view of the impact on the change of its structure of the IT cluster results. This choice is caused by global trends in the attractiveness and prospects of IT companies' products. While in 1991-1995, the cost of software products in the world comprised $32 \%$ of total costs, in 2014 - about $60 \%$ [12].

In Lviv region, the market growth of this industry in 2018 (according to expert estimates and results of the survey of the directors of IT companies located in Lviv) was from 457 million dollars to 518 million dollars, that is 177 million - 218 million dollars more than in 2015 and 361 million 
dollars - 415 million dollars - than in 2010 [13]. 12.403 million dollars was paid to the local budget of the IT enterprise in Lviv region [14].

According to the indicator "Number of IT specialists of Lviv to the total number of specialists in this industry in Ukraine", Lviv is third with a share of $10 \%$ after Kyiv with a share of $29 \%$ and Kharkiv region - $14 \%$. The share of the created workplaces is $13.8 \%$, as one IT specialist creates 3.37 of the workplace.

As the research shows, the IT industry has a significant impact on economic and social development and provides an external attractiveness of the region.

The indirect contribution of IT companies to the development of the regional economy by investing their employees' earnings (salaries) in various areas of the regional activity is sufficient, which contributes to the solution of regional social programs and through the tax payments of business entities of the region with goods and services used by IT specialists.

In 2018, the share of incomes of employees of the IT industry of Lviv region directed to charity amounted to 1.62 $\%$ (the contributions of IT workers of the region to charity for the year amounted to 2.7 million dollars).

The employees of IT sector of Lviv region put 66.3 million dollars for savings in banks. A total of $27.4 \%$ of IT professionals have deposits with banks, and overall $75.5 \%$ of employees make savings. On the average, savings in 2018 amounted to $20 \%$ of salaries. The main purpose of savings for IT workers $(46.4 \%)$ is the purchase of apartments. The percentage of savings from the salaries of IT specialists in Lviv region is $39.69 \%$ and equals to 66.3 million dollars.

The expenses of IT specialists in different spheres of economy of Lviv region are shown in Figure 1. The studies show that the largest expenditures of IT specialists in Lviv region are investment in the construction industry (56 million dollars), purchase of food, household (40.89 million dollars) and cars (19.2 million dollars).

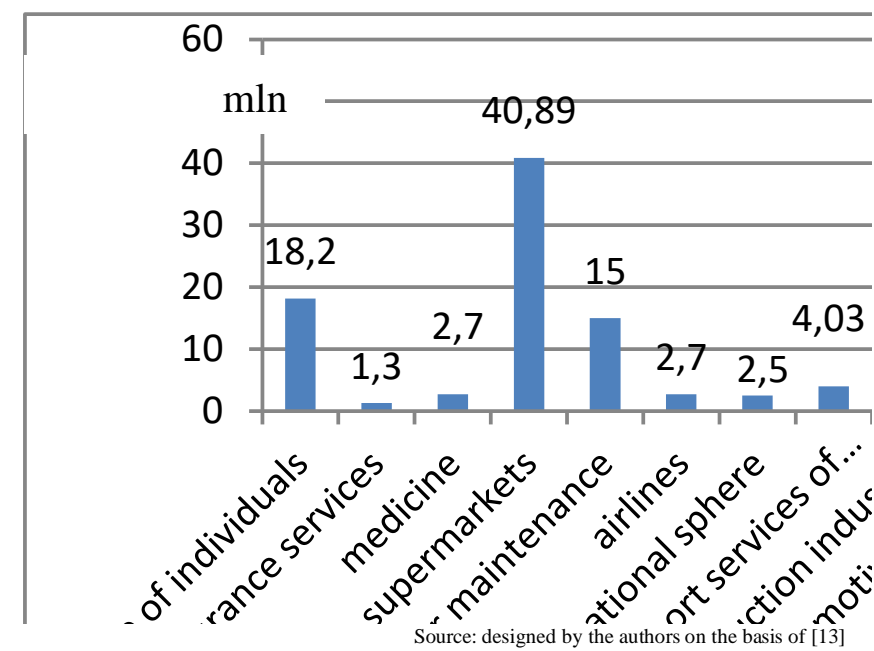

Fig. 1. The costs of IT specialists of Lviv region in different spheres of economy of the region.
The IT sector also has an indirect impact on the development of Lviv region through the introduction of certain products of the IT industry, which has not yet become decisive; however, it is promising because most IT companies operate under freelance conditions for the economies of different countries.

Currently, two products are highly effective for the development of the region, based on IT products related to the educational sector, provided by the system of children's electronic registration in kindergartens and transport services, which concerns the unloading of Lviv from cars and the arrangement of parking spaces. The planned and actual indicators of the IT industry contribution in Lviv region budget in 2018 through the programs under consideration are presented in Fig. 2. The values of plan and fact indicators are defined in percentage correlation of the data without the implementation of the proposed programs. The plan reflects the results that have already occurred in the implementation of the proposed programs, and the fact that it should be when the proposed programs are implemented as far as possible (to improve taking into account inaccuracies in the process of implementation).

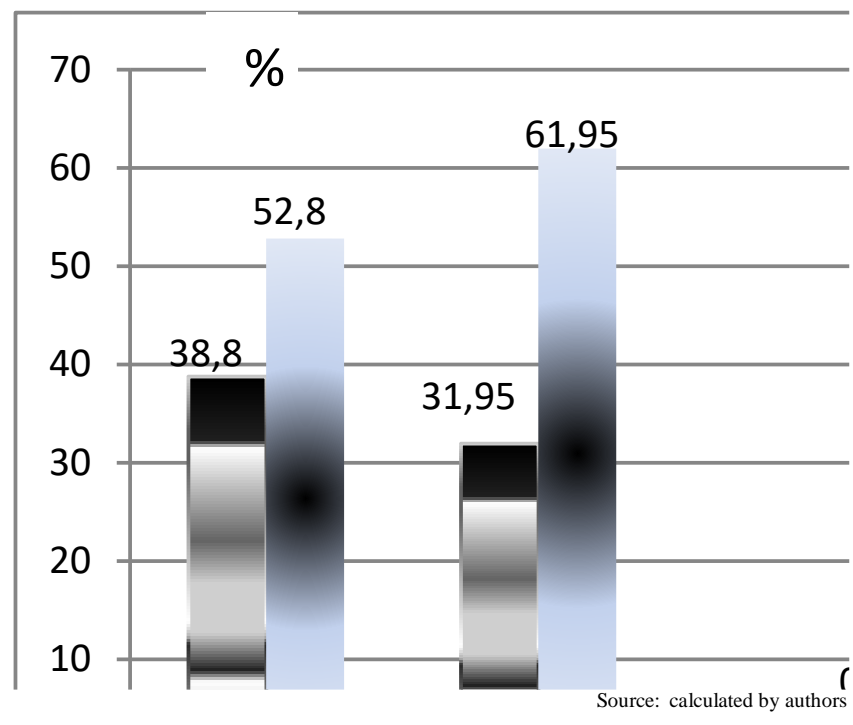

Fig. 2. The results of indirect impact of IT products on the growth of economy of Lviv region.

The data provided here demonstrates the effectiveness of IT products in the service sector. However, the scope of their impact should be much broader and promising in regional development through the development of IT products for the manufacturing sector.

\section{CHOICE OF STRATEGY FOR SUSTAINABLE DEVELOPMENT OF THE LVIV REGION}

In order to systematize, simplify, commensurate, mutual understand, avoid repetition when assessing the development of the region, it is advisable to determine the impact of its economic structures on the components economic, social, technological and external attractiveness, establishing appropriate relationships between their key elements, which establish conditions for their qualitative change in the region. 
To combine them, we propose to form a matrix in which on the $\mathrm{x}$-axis one should postpone qualitative parameters, and along the y-axis - quantitative. Herewith, to determine the desired directions of development of enterprises of one industry or group of enterprises of different industries within the region, it is necessary to construct quadrangles for each of the selected groups of enterprises with point $1,2,3,4$, reflecting respectively their economic, social, technological and external influence on the development of economic structures and the overall economy of the region.

Forming quadrilaterals separately for different groups of enterprises (formed according to fields of activity, sectoral affiliation, ownership forms, etc.) will help to form strategic directions of development for some of them, using opportunities by appropriate components (economic, social, technological and external attractiveness) of other interconnected entities, which will form the basis of the overall strategy for the sustainable development of the region. Another option is to build a common square on the results of activities and the level of mutual influence of all enterprises in the region and the choice of strategy depending on the prospects of development of a separate component shown in Fig. 3.

When constructing the matrix, we consider that the overall strategies for the regional development should correspond to possible behavior patterns in the international and national markets - protection, competition, survival and stability. The combination of economic indicators of the regional development with its external attractiveness and technological and technological breakthroughs of the industry with the external attractiveness of the region provides increasing opportunities for its growth and requires the formation of active measures of competitive struggle for its economic structures through leadership and escalation strategies, and a protective strategic direction for the regional development due to the strategies of conversion and borrowing. A defensive position can mean comfort before a jump - perhaps even through a jump to other regions.

The overall survival strategy refers to maximizing the use of the opportunities and potential prospects of regional economic entities to stabilize the situation in the region, and the strategy of moderate (sustainable) development ensuring the sustainable development of regional economic entities and creating the preconditions for effective sustainable development of the region.

Figure 3 presents the matrix of choice of the development strategy of Lviv region according to the above recommendations on the example of the impact on the region of IT cluster. Such a matrix will provide simplicity and transparency of calculations.

On the axes of the matrix, the integral actual and planned values of the impact of the IT cluster on the development of Lviv region are calculated taking into account each of the indicators presented in Fig. 4.

The choice of evaluation indicators (Fig. 4) of the impact of the IT cluster on the economic structures and Lviv region as a whole within certain components is made on the basis of the problems of regional development of Lviv region and the threats that mostly influence in this region on the activity of IT enterprises. This allows, as far as possible, to use the obtained evaluation results to formulate the most optimal ways of solving these problems.

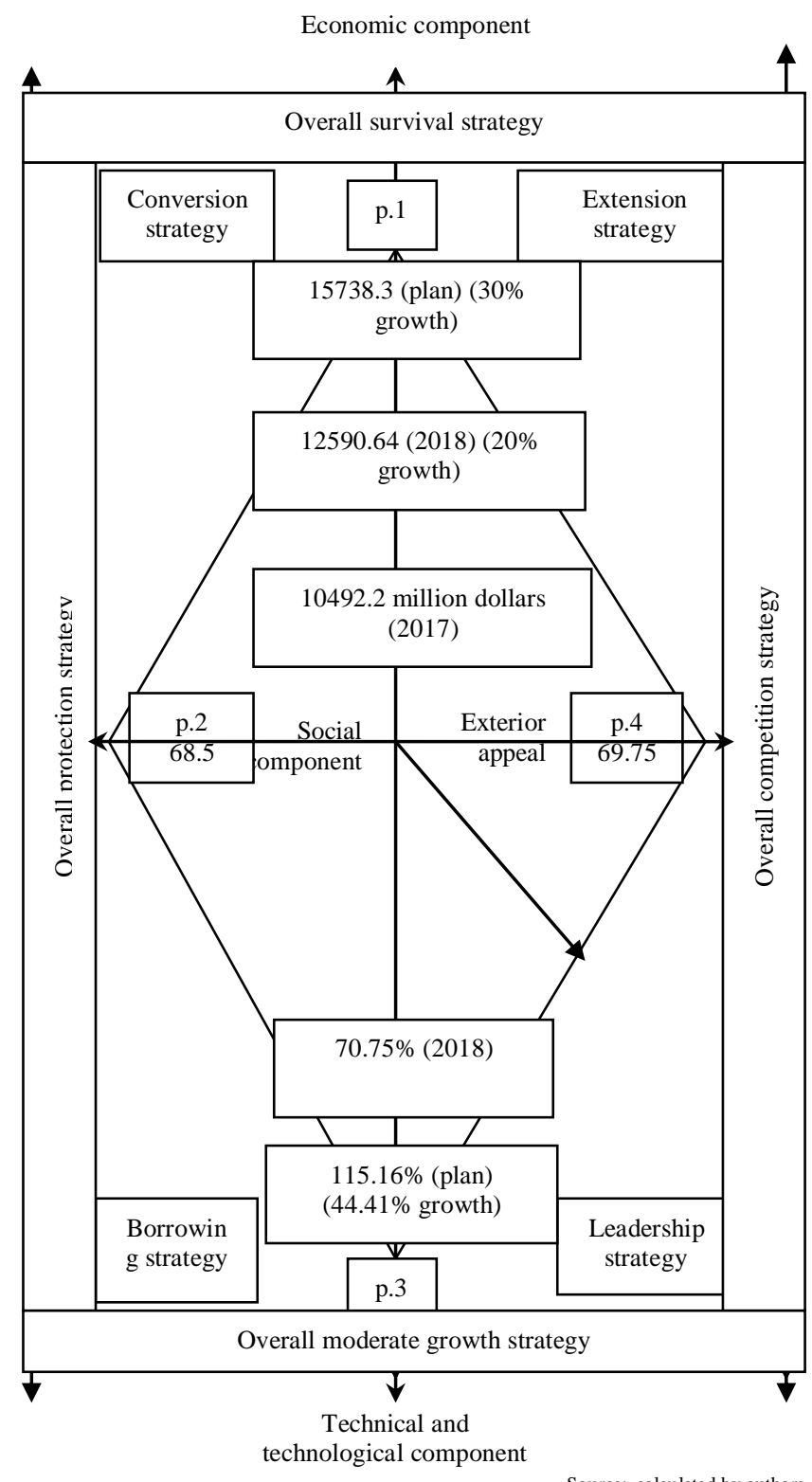

Fig. 3. The matrix of choice of the development strategy of Lviv region region with some influence by IT cluster.

The total value of the economic component in 2018 is 12590.64 million dollars, which is $20 \%$ more than in the previous year (in 2017, this amounted to 10492.2 million dollars) and represents the sum of the obtained values of the indicators "Revenues to the state budget", "Revenues in other spheres of economy of the region", "Export value" this year. According to the forecasts of the IT industry development, the value of this component is expected to grow up to $30 \%$ and accordingly the planned value of the regional development for this component will amount to 15738.3 mln USD.

The technical and technological component indicators 
will be calculated as a percentage of the growth of the reporting period indicator to the base (previous) year, taking into account the benefits brought to the region by the introduction of certain IT products of the industry, as well as the benefits that could be obtained as a result of product improvements on Fig. 2.

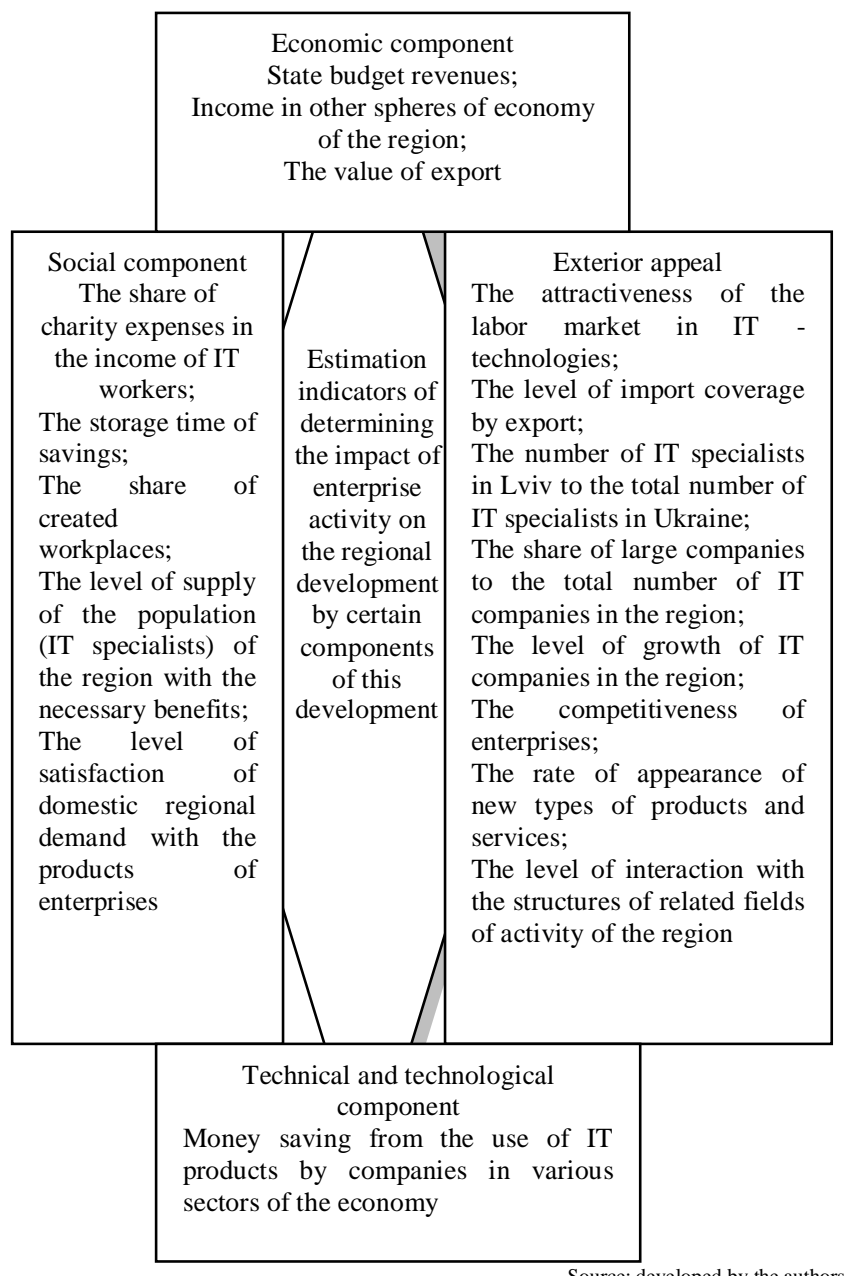

Fig. 4. Indicators for determining the impact of activity of a group of enterprises on the regional development

We computed the social component and the component of external attractiveness by the expert evaluation method by bringing the figures presented in Figs. 3 to a comparable view.

According to the obtained values of the indicators of the impact of the IT cluster on the state of Lviv region, it is advisable strategy of development of the region, with emphasis on the IT sphere through maximum assistance and directing its results to increase the efficiency of specific regional structures.

The implementation of the proposed measures will improve the overall situation in the region and increase the position of IT-enterprises in the sphere of activity or industry.

\section{CONCLUSION}

The surveys conducted confirm the necessity of taking into account business entities direct and mediate influence on economic figures of region development. Using the example of IT cluster example there was a dependence established of region development on cooperation of regional economic complex branches. The proposed methodological approach can be applied for determining a mutual influence of business entities on economy and choice of strategy for sustainable development of the region.

\section{REFERENCES}

[1] S. I. Bohuslavska, "Key elements of strategic management of the development of regional socio-economic systems", Global and National Economic Problems URL. [Online]. Available: http://globalnational.in.ua/archive/11-2016/118.pdf. [in Ukrainian].

[2] P. V. Vorona, "Formation of Regional Development Strategy", Current problems of public administration: collection of research papers, No. 1 (41), p. 222-230, 2012. [Online]. Available: http://www.kbuapa.kharkov.ua/e-book/apdu/2012-1/2012_01.pdf . [in Ukrainian].

[3] Z.V. Herasymchuk, and O.V. Sereda, "State, Problems and Prospects of Strategic Urban Development Management in Ukraine", Collection of scientific works Lutsk National Technical University. Economic Sciences, Part 1, Issue 9 (35), p. 104-111, 2012. [in Ukrainian].

[4] R. Jovovic, M. Draskovic, M. Delibasic, and M. Jovovic, "The concept of sustainable regional development - institutional aspects, policies and prospects", Journal of International Studies, no.10(1), pp. 255-266. doi:10.14254/2071-8330.2017/10-1/18.

[5] O. S. Kachnyi, "Regional development strategy as a means of orientation (definition of models) of regional socio-economic development", Public Administration: Improvement and Development, No. 12, 2017. [Online]. Available: http://www.dy.nayka.com.ua/?op=1. [in Ukrainian].

[6] O.I. Karyi, "Stages of strategic planning of the urban development: generalization of existing methods". [Online]. Available: http://www.nbuv.gov.ua/portal/Soc_Gum/En_re/2010_7_3/8.pdf. [in Ukrainian].

[7] L.I. Katan, "The directions for the development of management of the agro-industrial system of Ukraine: ecological and economic aspect". [Online]. Available: http://library.kpi.kharkov.ua/Vestnik/2010_8/statiZKatan.pdf. [in Ukrainian].

[8] T. V. Kravchenko, "Substantiation of the choice of strategy of economic regional development", East European scientific journal, Vol. 2, No.2 (2), p. 33-39, 2015.

[9] O. F. Novikova et al., Sustainable development of the industrial region: social aspects. Donetsk, Ukraine: Institute of Industrial Economy, 2012. [in Ukrainian].

[10] M.I. Zvшereakov, A.I. Kovaliov, and N. V. Smentina, Strategic planning of the balanced development of territorial socio-economic systems in the conditions of decentralization. Odessa, Ukraine: ONEU, 2017. [in Ukrainian].

[11] O.V. Prokopenko et al., Sustainable development of the enterprise, region, society: innovative approaches to supply. Poland: Drukarnia and Studio Graficzne Omnidium, 2014. [in Russian].

[12] H. S. Terletska, and O. V. Babych, "Information technologies in the services market: problems, changes, development", Effective Economics, No. 6, 2014. [in Ukrainian].

[13] Research of the IT market in Lviv [Online]. Available: https://itcluster.lviv.ua/wp-content/uploads.pdf . [in Ukrainian].

[14] General Directorate for Statistics in Lviv Region. Statistics - Kyiv, 1999-2017. [Online]. Available: http://www.lv.ukrstat.gov.ua/eng/si/inf_2009.php?ind_page=s. [in Ukrainian]. 